\title{
Association between Psychological Stress and Periodontitis: A Systematic Review
}

\author{
Micaele M. L. Castro ${ }^{1}$ Railson de O. Ferreira ${ }^{1}$ Nathalia C. F. Fagundes ${ }^{2}$ Anna P. C. P. S. C. Almeida ${ }^{1}$ \\ Lucianne C. Maia ${ }^{3}$ Rafael R. Lima ${ }^{1}$
}

${ }^{1}$ Laboratory of Functional and Structural Biology, Institute of Biological Sciences, University Federal do Pará, Rua Augusto Corrêa 1, Guamá, Belém, PA, Brazil

${ }^{2}$ School of Dentistry, Faculty of Medicine and Dentistry, University of Alberta. 5528 Edmonton Clinic Health Academy, Edmonton, Canada

${ }^{3}$ Department of Pediatric Dentistry and Orthodontics, School of

Dentistry, Universidade Federal do Rio de Janeiro, Rio de Janeiro, Brazil

\begin{abstract}
Address for correspondence Rafael Rodrigues Lima, PhD, Laboratory of Functional and Structural Biology, Institute of Biological Sciences, University Federal do Pará, Rua Augusto Corrêa 1, Guamá, 66075-900 Belém, PA, Brazil (e-mail: rafalima@ufpa.br).
\end{abstract}

Eur ] Dent 2020;14:171-179

\begin{abstract}
This systematic review aims to investigate the association between psychological stress and periodontitis through analysis of cortisol levels and periodontal clinical parameters. This review was conducted according to the Preferred Reporting Items for Systematic Reviews and Meta-Analyses (PRISMA) guide and based on PECO (Participants, Exposure, Comparators, Outcomes) question and registered at PROSPERO under the code CRD42017076670. As eligibility criteria, observational studies performed in adult humans presenting periodontitis $(\mathrm{P})$, which evaluated patients exposed $(E)$ and nonexposed to psychological stress $(C)$ and to verify the association between this type of stress and periodontitis $(\mathrm{O})$ were included. The searches were performed until March 2018. The following databases were used: PubMed, Scopus, Web of Science, The Cochrane Library, LILACS, OpenGrey, and Google Scholar. After searches, the duplicate results were removed. The remaining citations were selected according to eligibility criteria in two phases. In the first phase, the title/abstract was evaluated. In the second phase, the articles were chosen previously were assessed by full text. After selection, the studies were submitted to data extraction and risk of bias evaluation by Fowkes and Fulton. A total of 1,386 citations were retrieved. After dupli-

Keywords

- stress

- psychological

- periodontitis

- periodontal disease

- systematic review cates removal and selection process, three articles were selected by full text. Among them, two articles reported a positive association between psychological stress and periodontitis. All articles were classified as low risk of bias. Even though two articles highlighted an association between psychological stress and the presence of a possible modulatory pattern of cortisol levels in clinical parameters of periodontitis, more studies are necessary to elucidate this question.
\end{abstract}

\section{Introduction}

The periodontitis is a chronical inflammation caused by bacteria, mostly gram negative. ${ }^{1}$ The interaction of systemic conditions and oral microbiota modulates the severity of this disease. ${ }^{2,3}$ As a consequence of this process, damage to periodontal tissue, especially on the alveolar bone and periodontal ligament, can be observed. ${ }^{4,5}$
The beginning and the progression of periodontitis, as well as other chronical diseases, are associated with many risk factors, such as diabetes, smoking, age, and genetic predisposition. ${ }^{6,7}$ Psychological factors, such as anxiety and depression, are associated with changes in immune response, which can increase periodontitis susceptibility. ${ }^{8-11}$

The stress also presented a role of modulation in immune response $^{12}$ due to their reduction in defense capacity. 
As a consequence of this mechanism, the organism turns more susceptible to develop psychosomatic and inflammatory diseases. ${ }^{13,14}$ This modulation may favor the beginning or progression of periodontal disease ${ }^{15,16}$ since stressors can aggravate damage to the supporting and protect tissues of the tooth. ${ }^{17}$

This systematic review sought to investigate the clinical evidence of the association between chronical psychological stress and periodontitis in humans.

\section{Methods}

\section{Protocol and Registry}

This systematic review was registered at PROSPERO under the code CRD42017076670. This database is from University of York and is responsible for recording and disseminating systematic reviews. This systematic review was performed according to Preferred Reporting Items for Systematic Reviews and Meta-Analyses (PRISMA) ${ }^{18}$ guidelines and the Cochrane's protocol (Supplementary Table S1, online only). ${ }^{19}$

\section{Selection Criteria}

In this review, we aimed to answer the following question: "Is the psychological stress is associated with periodontitis?." The eligibility criteria were defined according to PECO strategy. This acronym represents the patient $(P)$, exposition $(E)$, comparison $(\mathrm{C})$, and outcome $(\mathrm{O})$ characteristics of the eligible question. Only observational studies, with an adult human population $(\mathrm{P})$, which evaluate exposed (E) and nonexposed patients to psychological stress (C), assess the association between stress and periodontitis $(0)$ were included in this review.

Case reports, reviews, descriptive studies, opinion articles, technical articles, animal studies, and in vitro studies were excluded.

\section{Search Strategy}

The searches were performed on the following electronic databases: PubMed, Scopus, Web of Science, Lilacs, and Cochrane Library. The Google Scholar and OpenGrey were used as gray literature sources. No restriction of year or language of publication was applied. The search strategy was composed of MeSH and free terms and was adapted according to each database (Supplementary Table S2, online only).

The searches were performed until March 2018. Additionally, an alert was created in each database to retrieve new studies according to eligibility criteria. After searches, the citations found in each database were exported to a reference manager software (EndNote, X7 version, Thomson Reuters, Philadelphia, United States). The articles presented in more than one database were considered only once.

\section{Process of Selecting Studies}

After the importation of citations, the duplicate results were removed. The selection process was divided into two phases, according to eligibility criteria. In the first phase, all citations were evaluated by two reviewers (MMLC and ROF) and checked by a third reviewer in case of disagreement (RRL), regarding title and abstract. In phase II, the articles selected on phase I were evaluated by full-text, following the same criteria and method described on phase I. Additionally, the references of the chosen articles on phase II were checked for further studies.

\section{Quality Assessment and Risk of Bias}

The Fowkes and Fulton's checklist ${ }^{20}$ was used in this systematic review to evaluate the quality and risk of bias of the included studies. In this checklist, the quality of the articles was assessed by seven central domains: "Study design appropriate to the objective?"; "Study sample representative?"; "Control group acceptable?"; "Quality of measurements and outcomes?"; "Completeness?"; "Distorting influences?"

For each question, it was attributed a 0 (no problem), + (minor problem) or ++ (major problem). The criteria for this evaluation were standardized by evaluators and adapted from Fowkes and Fulton ${ }^{20}$ and Almeida et $\mathrm{al}^{21}$ ( - Table $\mathbf{1}$ ).

The risk of Bias was evaluated following three summary questions presented at the end of the checklist: "Bias: Are the results erroneously biased in a certain direction?," "Confounding: Are there any serious confusing or other distorting influences?" and "Chance: Is it likely that the results occurred by chance?" In each question, a "Yes" or "No" was attributed to an answer. In case of a "No" answered in all questions, the study was considered as a low risk of Bias.

\section{Data Extraction}

The data regarding the country, year, study design, sample characteristics (sample source and size), age, periodontitis evaluation, stress evaluation (cortisol levels measurement), results, and statistical analysis were extracted from all articles included after the selection process. This process was performed by two reviewers (MMLC and ROF) and checked by a third reviewer in case of disagreement (RRL).

\section{Results}

\section{Studies Included}

A total of 2,373 articles were retrieved after searches and 1,386 remained after the exclusion of duplicates. From these, five articles were selected on phase I. ${ }^{22-26}$ Among them, two articles were excluded due to the absence of periodontitis evaluation $^{23,26}$ ( - Fig. 1).

\section{Description of the Study Characteristics}

As a result, three articles were included in this review. According to study design, two were cross-sectional studies, ${ }^{24,25}$ and the other one was a case-control ${ }^{22}$ (- Table 2).

Two articles reported an association between psychological stress and periodontitis ${ }^{24,25}$, indicating an increase on clinical attachment loss (CAL), probing depth (PB), and bleeding on probing. One study ${ }^{22}$ did not report an association between the evaluated conditions, indicating similar levels of PD and CAL in stressed and nonstressed patients.

Regarding the stress evaluation, only studies that included the cortisol levels measurement were added, due to the increase in these levels caused by psychological stress. ${ }^{13}$ Two 
Table 1 Domains and risk of bias considered in risk of bias evaluation according to Fowkes and Fulton

\begin{tabular}{|c|c|c|}
\hline Guidelines & Checklist & Description \\
\hline \multirow{5}{*}{$\begin{array}{l}\text { Study design } \\
\text { appropriate to } \\
\text { objectives? }\end{array}$} & Objective common design & \multirow{5}{*}{$\begin{array}{l}\text { The type of study was marked in the appropriate type of study. If the type of } \\
\text { study was appropriate according to the study design, it was labeled as " } 0 \text {," and } \\
\text { as "++" if it was not appropriate }\end{array}$} \\
\hline & Prevalence cross-sectional & \\
\hline & Prognosis cohort & \\
\hline & Treatment controlled trial & \\
\hline & $\begin{array}{l}\text { Cause cohort, case- } \\
\text { control, cross-sectional }\end{array}$ & \\
\hline \multirow[t]{5}{*}{$\begin{array}{l}\text { Study sample } \\
\text { representative? }\end{array}$} & Source of sample & $\begin{array}{l}\text { The domain was considered " } 0 \text { " in cases of detailed origin, "+" to a specified } \\
\text { origin of only one group and "++" in cases of absence of specification of the } \\
\text { source of the groups }\end{array}$ \\
\hline & Sampling method & $\begin{array}{l}\text { The item was assigned "0" for a full description of sampling method, "+" } \\
\text { for poor or no explanation of sample method, with no problem in matching } \\
\text { between groups, and "++" for poor or no description of sample method, inter- } \\
\text { fering in the matching of the groups }\end{array}$ \\
\hline & Sample size & $\begin{array}{l}\text { A minor problem "+" was considered when the sample was not representative } \\
\text { or did not report a sample calculation. To a major problem, "++" was consid- } \\
\text { ered when no sample calculation was provided, and the number of partici- } \\
\text { pants was less than } 50 \text { participants, " } 0 \text { " was considered in the absence of the } \\
\text { above factors }\end{array}$ \\
\hline & Entry criteria/exclusion & $\begin{array}{l}\text { A minor problem "+" was attributed when the control and case group report- } \\
\text { ed current use of antibiotics or anti-inflammatories, diabetes, smoking or } \\
\text { pregnancy. In the case of presence of more than two previously mentioned } \\
\text { items, it was considered as a major problem "++" }\end{array}$ \\
\hline & Nonrespondents & $\begin{array}{l}\text { The "0" was attributed when there was no refusal to participate in the study, } \\
\text { "+" was assigned when there was the refusal, but did not compromise the } \\
\text { sample, and "++" when there were refusal and impairment of the sample size }\end{array}$ \\
\hline \multirow[t]{4}{*}{$\begin{array}{l}\text { Control group } \\
\text { acceptable? }\end{array}$} & Definition of controls & $\begin{array}{l}\text { It was attributed "0" when all characteristics of the control group were } \\
\text { described, "+" when any information was pendent as the origin of the control } \\
\text { group, the selection criterions and a different origin between case and control } \\
\text { groups and "++" when two or more items described in previously items }\end{array}$ \\
\hline & Source of controls & $\begin{array}{l}\text { It was considered "0" when the control group was referred, "+" when the } \\
\text { origin of groups was different, but with reasons and "++" when the groups } \\
\text { presented different origins without reasons }\end{array}$ \\
\hline & Matching/randomization & $\begin{array}{l}\text { In this item, "0" was assigned to cases of randomized/matched groups, "+" to } \\
\text { cases of no description of randomization, but with a matching of groups and } \\
\text { "++" to no explanation of randomization or matching }\end{array}$ \\
\hline & $\begin{array}{l}\text { Comparable } \\
\text { characteristics }\end{array}$ & $\begin{array}{l}\text { It was attributed "0" to matched groups or not matched by the impossibility } \\
\text { of being subsequently adjusted and "++" the presence of unpaired variables } \\
\text { that were not paired or adjusted }\end{array}$ \\
\hline \multirow[t]{4}{*}{$\begin{array}{l}\text { Quality of } \\
\text { measurements } \\
\text { and outcomes? }\end{array}$} & Validity & $\begin{array}{l}\text { It was considered "0" when the evaluation method applied is appropriate; } \\
\text { "+" when using a single method, but with appropriate sensitivity with good } \\
\text { specificity; "++" when using a single method, without an adequate specificity } \\
\text { or good sensitivity }\end{array}$ \\
\hline & Reproducibility & $\begin{array}{l}\text { It was considered "0" whether the evaluation methods were well described; } \\
\text { "+" when a lack description of any step of the method was presented, for } \\
\text { example, the identification of the patients of the groups studied in laboratory } \\
\text { samples, evaluations at different times or application of various methods be- } \\
\text { tween groups of individual pathology; "++" when two or more of the previous } \\
\text { items are present }\end{array}$ \\
\hline & Blindness & $\begin{array}{l}\text { The condition of the study participants was considered to be "Blind," in this } \\
\text { case being assigned the signal " } 0 \text {," in cases of "not blind" the signal "++" was } \\
\text { attributed }\end{array}$ \\
\hline & Quality control & $\begin{array}{l}\text { It was considered a problem when the examiner was not qualified; a partial } \\
\text { periodontal exam was performed [not in all teeth or not in all the six peri- } \\
\text { odontal sites/teeth], the measurement of periodontitis was only radiographic } \\
\text { or the absence of the number of evaluated teeth sites. A minor problem "+" } \\
\text { was considered when two of these characteristics were present, and a major } \\
\text { problem "++" if more than two of these characteristics were present }\end{array}$ \\
\hline
\end{tabular}


continued

\begin{tabular}{|c|c|c|}
\hline Guidelines & Checklist & Description \\
\hline \multirow[t]{4}{*}{ Completeness } & Compliance & $\begin{array}{l}\text { It was assigned "0" for a sample size that remains the same from the begin- } \\
\text { ning to the end or decreases without compromising the power of the test; "+" } \\
\text { for differences in sample size at the end of the study, compromising the power } \\
\text { of the test, but with reasons and adjusts; "++" for difference in sample size at } \\
\text { the end of the study, compromising the power of the test, without reasons }\end{array}$ \\
\hline & Dropouts & $\begin{array}{l}\text { The "0" was scored when there is no loss during the study, "+" when there is } \\
\text { a withdrawal that involves the inclusion criteria, such as age, sex, "++" when } \\
\text { there is withdrawal and it compromises more than one criterion }\end{array}$ \\
\hline & Deaths & This item was scored as Not Applicable "NA," due to the type of PECO strategy \\
\hline & Missing data & $\begin{array}{l}\text { In this item, "0" was assigned to cases of randomized/matched groups, "+" to } \\
\text { cases of no description of randomization, but with a matching of groups and } \\
\text { "++" to no description of randomization or matching }\end{array}$ \\
\hline \multirow[t]{5}{*}{$\begin{array}{l}\text { Distorting } \\
\text { influences? }\end{array}$} & Extraneous treatments & $\begin{array}{l}\text { In this item, "0" was considered when there were no external influences; "+" } \\
\text { when there are external influences, but that does not interfere in the results; } \\
\text { "++" when there are external influences and interferes with the results }\end{array}$ \\
\hline & Contamination & This item was scored as Not Applicable "NA," due to the type of PECO strategy \\
\hline & Changes over time & $\begin{array}{l}\text { In this item, "0" was attributed to data collected in the same period; "+" to } \\
\text { data obtained from the control group and the study group at different times } \\
\text { that may cause distortions; "++" when the previous item was associated with } \\
\text { data from studies already published }\end{array}$ \\
\hline & Confounding factors & $\begin{array}{l}\text { A problem was assigned when the data analysis involved enrollment of per- } \\
\text { sons }<5 \text { years. Menopausal woman, smokers, diabetics and obese. A minor } \\
\text { problem "+" was assigned when } 1 \text { or } 2 \text { of these characteristics were present } \\
\text { and a major problem "++" if there were } 3 \text { or more }\end{array}$ \\
\hline & $\begin{array}{l}\text { Distortion reduced by } \\
\text { analysis }\end{array}$ & $\begin{array}{l}\text { It was considered "0" when it cites the adjustments of the covariates that } \\
\text { present distortions; “+" when the article report adjustment, but does not say } \\
\text { the criteria; "++" when distortion was identified, without adjustment }\end{array}$ \\
\hline \multirow[t]{3}{*}{$\begin{array}{l}\text { Summary } \\
\text { questions }\end{array}$} & $\begin{array}{l}\text { Bias: Are the results } \\
\text { erroneously biased in a } \\
\text { certain direction? }\end{array}$ & \multirow[t]{3}{*}{$\begin{array}{l}\text { YES or "NO" answers were assigned to each question. If the answer is NO to } \\
\text { the three questions, the article is considered reliable, with low risk of bias }\end{array}$} \\
\hline & $\begin{array}{l}\text { Confounding: Are there } \\
\text { any serious confusing } \\
\text { or other distorting } \\
\text { influences? }\end{array}$ & \\
\hline & $\begin{array}{l}\text { Chance: Is it likely that } \\
\text { the results occurred by } \\
\text { chance? }\end{array}$ & \\
\hline
\end{tabular}

articles measured salivary cortisol levels ${ }^{22,24}$ and Ishisaka et al 2008 evaluated serum cortisol. These levels were measured by radioimmunoassay ${ }^{24,25}$ and enzyme-linked immunosorbent assay ${ }^{22}$ on the included studies.

\section{Quality Assessment and Risk of Bias}

During our analysis, we considered that some factors to reduce the risk of bias could favor the applicability of this review and promote conclusions of the association between stress and periodontitis. Among them, the inclusion and exclusion criteria approved groups that presented similar characteristics differing only in the presence/ absence of stress criterion. Thus, the variables stress and periodontitis were the primary variables related to the outcome.

All studies were classified with low risk of bias. The main problems observed among articles were related to sampling method, sample size, randomization/matching, and confounding factors ( - Table $\mathbf{3}$ ).
All studies presented a major problem on sampling method due to the absence of a random sample. ${ }^{22,24,25}$ Regarding sample size, a minor problem was reported in two studies ${ }^{24,25}$ due to the lack of sample size calculation.

In the domain "Control group acceptable?," all articles presented a minor problem due to the absence of description of randomization/matching process.

The selected articles $22,24,25$ presented valid methods periodontitis and stress evaluation, such as the American Academy of Periodontology classification ${ }^{27}$ and the assessment of salivary and blood cortisol, respectively. However, a minor problem was attributed to validity question on Bakri et al $2013^{22}$ part of the domain: "Quality of measurements and outcomes?" This problem was observed due to the absence of calibration among evaluators.

Besides the standardized methods, the presence of blinded evaluators and the use of statistical methods to reduce the confounding factors may reduce the risk of Bias of the included studies. 


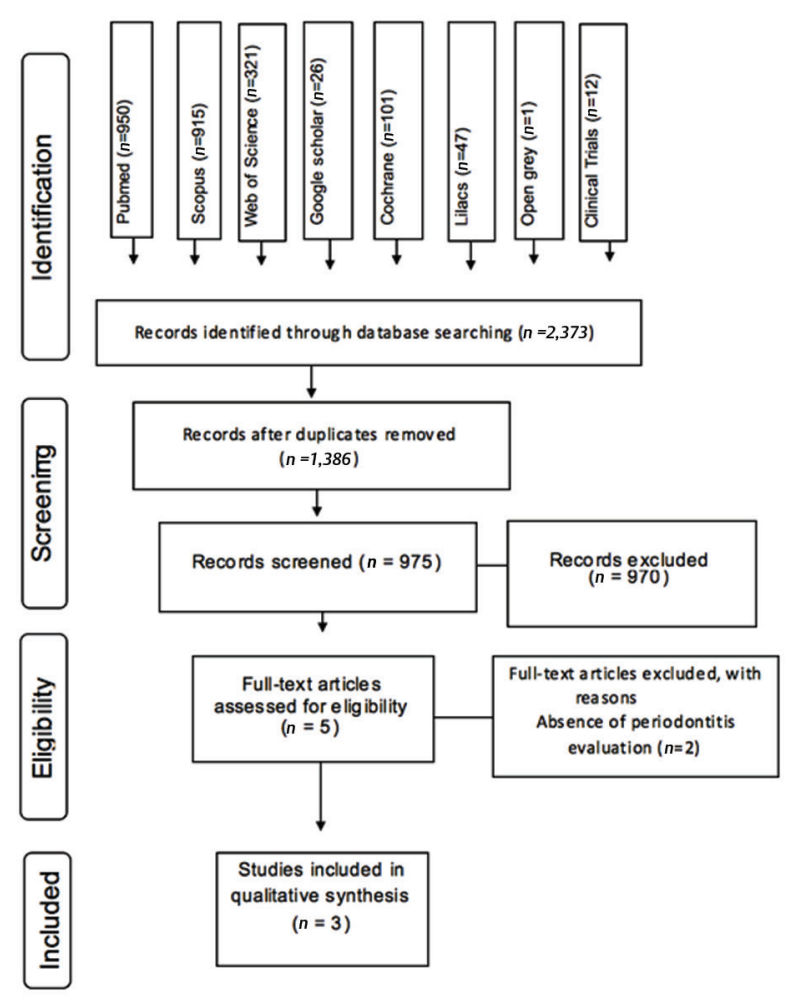

Fig. 1 Flow diagram of literature search according to Preferred Reporting Items for Systematic Reviews and Meta-Analyses (PRISMA) statement.

\section{Discussion}

In this systematic review, three articles respected the eligibility criteria and were included. Among them, two studies reported an association between psychological stress and periodontitis. $^{24,25}$

Systematic reviews judiciously gather studies with the purpose of synthesizing the clinical situations through strategies that allow the critical evaluation of these studies. This research method helps to summarize clinical questions and the clinical decisions of medical professionals. ${ }^{28}$

This systematic review aimed to evaluate the association between psychological stress and periodontitis. Association could mean (1) that periodontitis is caused by stress, (2) that stress is caused by periodontitis, and finally (3) that both phenomena are just correlated because they a driven by other factors. In this case, specially, our PECO strategy helps our study to find studies that research the influence of the psychological stress on periodontitis. Other important difference is that each included study our systematic review evaluates stress marker and clinical parameters, excluding articles that subjectively analyze from both conditions.

This systematic review aimed to evaluate the association between psychological stress and periodontitis. Among the three included studies, $22,24,25$ two reported that higher levels of cortisol were associated with a worsening of periodontitis. $^{24,25}$ The cortisol, glucocorticoid stress biomarker, is

Table 2 Summary of characteristics of the included studies

\begin{tabular}{|c|c|c|c|c|c|c|c|}
\hline \multirow{3}{*}{$\begin{array}{l}\text { Author, year, } \\
\text { country; } \\
\text { design }\end{array}$} & \multicolumn{2}{|c|}{ Sample } & \multicolumn{4}{|l|}{ Age } & \multirow[t]{3}{*}{ Results } \\
\hline & & & \multirow{2}{*}{$\begin{array}{l}\text { Mean } \\
( \pm S D), \text { in } \\
\text { years }\end{array}$} & \multicolumn{3}{|c|}{ Methods of evaluation } & \\
\hline & Source & Size & & $\begin{array}{l}\text { Periodon- } \\
\text { titis }\end{array}$ & Cortisol levels & $\begin{array}{l}\text { Statistical } \\
\text { analysis }\end{array}$ & \\
\hline \multirow{3}{*}{$\begin{array}{l}\text { Ishisaka } \\
\text { et al } 2008^{25} ; \\
\text { Japan; } \\
\text { cross-sectional }\end{array}$} & \multirow{3}{*}{$\begin{array}{l}\text { Fu- } \\
\text { kuoka, } \\
\text { Japan }\end{array}$} & 467 & \multirow[t]{3}{*}{$62.6 \pm 2.89$} & \multirow{3}{*}{$\begin{array}{l}\text { CAL, BOP, } \\
\text { and PD. }\end{array}$} & \multirow{3}{*}{$\begin{array}{l}\text { Radioimmunoas- } \\
\text { say, seric levels. }\end{array}$} & \multirow[t]{3}{*}{ Kruskal-Wallis } & \multirow{3}{*}{$\begin{array}{l}\text { An association between } \\
\text { cortisol and CAL levels was } \\
\text { detected ( } p=0.11) \text {, with } \\
\text { higher levels of cortisol in sites } \\
\text { with elevated CAL }\end{array}$} \\
\hline & & $\begin{array}{l}\text { Con- } \\
\text { trol: } \\
107\end{array}$ & & & & & \\
\hline & & $\begin{array}{l}\text { Stress: } \\
187\end{array}$ & & & & & \\
\hline \multirow{3}{*}{$\begin{array}{l}\text { Hilgert et al } \\
\text { 2006 } 24 ; \text { Brazil; } \\
\text { cross-sectional }\end{array}$} & \multirow{3}{*}{$\begin{array}{l}\text { Porto } \\
\text { Alegre, } \\
\text { Brazil }\end{array}$} & 235 & $\begin{array}{l}\text { Control: } \\
61.4 \pm 7.2\end{array}$ & \multirow[t]{3}{*}{$\begin{array}{l}\text { CAL, BOP } \\
\text { and PD. }\end{array}$} & \multirow{3}{*}{$\begin{array}{l}\text { Radioimmuno- } \\
\text { assay, salivary } \\
\text { levels. }\end{array}$} & \multirow{3}{*}{$\begin{array}{l}\text { Multivari- } \\
\text { ate logistic } \\
\text { regression }\end{array}$} & \multirow{3}{*}{$\begin{array}{l}\text { Cortisol levels were positively } \\
\text { associated with a } C A L \geq 4 \mathrm{~mm} \\
(\mathrm{OR}=5.1,95 \% \mathrm{CI}[1.2,20.7]) \text {; } \\
30 \% \text { of sites with } \mathrm{CAL} \geq 5 \mathrm{~mm} \\
(\mathrm{OR}=6.9,95 \% \mathrm{Cl}[1.7,27.1]) ; \\
\text { and } 26 \% \text { of sites with } \\
\mathrm{PD} \geq 4 \mathrm{~mm}(\mathrm{OR}=10.7,95 \% \\
\mathrm{Cl}[1.9,54.1]) \text { after adjusting } \\
\text { for confounding variables }\end{array}$} \\
\hline & & $\begin{array}{l}\text { Con- } \\
\text { trol: } \\
212\end{array}$ & $\begin{array}{l}\text { Stress: } \\
61.6 \pm 8.3\end{array}$ & & & & \\
\hline & & $\begin{array}{l}\text { Stress: } \\
23\end{array}$ & & & & & \\
\hline \multirow{3}{*}{$\begin{array}{l}\text { Bakri et al, } \\
2013^{22} ; \text { United } \\
\text { Kingdom; } \\
\text { case-control }\end{array}$} & \multirow{3}{*}{$\begin{array}{l}\text { Shef- } \\
\text { field, } \\
\text { United } \\
\text { King- } \\
\text { dom }\end{array}$} & 45 & $\begin{array}{l}\text { Control: } \\
49.8 \pm 9.7\end{array}$ & \multirow{3}{*}{$\begin{array}{l}\text { CAL, BOP, } \\
\text { PD, tooth } \\
\text { mobility, } \\
\text { Gingival } \\
\text { recession }\end{array}$} & \multirow[t]{3}{*}{$\begin{array}{l}\text { ELISA (salivary } \\
\text { levels) }\end{array}$} & \multirow[t]{3}{*}{$\begin{array}{l}\text { Student's } \\
\text { t-test }\end{array}$} & \multirow{3}{*}{$\begin{array}{l}\text { No difference between } \\
\text { means of CAL and PD IN } \\
\text { stressed and nonstressed } \\
\text { patients was detected }\end{array}$} \\
\hline & & $\begin{array}{l}\text { Con- } \\
\text { trol:16 }\end{array}$ & $\begin{array}{l}\text { Stress: } \\
44.6 \pm 10.4\end{array}$ & & & & \\
\hline & & $\begin{array}{l}\text { Stress: } \\
29\end{array}$ & & & & & \\
\hline
\end{tabular}

Abbreviations: BOP, bleeding on probing; CAL, clinical attachment loss; Cl, confidence interval; OR, odds ratio; PD, probing depth; SD, standard deviation. 
Table 3 Quality assessment of studies included, according to Fowkes and Fulton, 1991

\begin{tabular}{|c|c|c|c|c|}
\hline Guideline & Checklist & $\begin{array}{l}\text { Hilgert et al } \\
2006^{24}\end{array}$ & $\begin{array}{c}\text { Ishisaka et al } \\
2008^{25}\end{array}$ & $\begin{array}{c}\text { Bakri et al } \\
2013^{22}\end{array}$ \\
\hline \multirow{5}{*}{$\begin{array}{l}\text { Study design appropriate to } \\
\text { objectives? }\end{array}$} & Objective common design & - & - & - \\
\hline & Prevalence cross-sectional & - & - & - \\
\hline & Prognosis cohort & - & - & - \\
\hline & Treatment controlled trial & - & - & - \\
\hline & Cause cohort, case-control, cross-sectional & 0 & 0 & 0 \\
\hline \multirow[t]{5}{*}{ Study sample representative? } & Source of sample & 0 & 0 & 0 \\
\hline & Sampling method & ++ & ++ & ++ \\
\hline & Sample size & + & + & 0 \\
\hline & Entry criteria/exclusion & 0 & 0 & 0 \\
\hline & Nonrespondents & + & 0 & 0 \\
\hline \multirow[t]{4}{*}{ Control group acceptable? } & Definition of controls & 0 & 0 & 0 \\
\hline & Source of controls & 0 & 0 & 0 \\
\hline & Matching/randomization & + & + & + \\
\hline & Comparable characteristics & 0 & 0 & 0 \\
\hline \multirow{4}{*}{$\begin{array}{l}\text { Quality of measurements and } \\
\text { outcomes? }\end{array}$} & Validity & 0 & 0 & + \\
\hline & Reproducibility & 0 & 0 & 0 \\
\hline & Blindness & 0 & 0 & 0 \\
\hline & Quality control & 0 & 0 & 0 \\
\hline \multirow[t]{4}{*}{ Completeness } & Compliance & 0 & 0 & 0 \\
\hline & Dropouts & 0 & 0 & 0 \\
\hline & Deaths & NA & NA & NA \\
\hline & Missing data & 0 & 0 & 0 \\
\hline \multirow[t]{5}{*}{ Distorting influences? } & Extraneous treatments & 0 & 0 & 0 \\
\hline & Contamination & NA & NA & NA \\
\hline & Changes over time & 0 & 0 & 0 \\
\hline & Confounding factors & + & + & 0 \\
\hline & Distortion reduced by analysis & 0 & 0 & 0 \\
\hline \multirow[t]{3}{*}{ Summary questions } & $\begin{array}{l}\text { Bias: Are the results erroneously biased in a } \\
\text { certain direction? }\end{array}$ & No & No & No \\
\hline & $\begin{array}{l}\text { Confounding: Are there any serious confusing } \\
\text { or other distorting influences? }\end{array}$ & No & No & No \\
\hline & $\begin{array}{l}\text { Chance: Is it likely that the results occurred by } \\
\text { chance? }\end{array}$ & No & No & No \\
\hline
\end{tabular}

$0=$ no problem; + = minor problem; ++ = major problem; NA = not applicable.

responsible for maintaining the homeostasis of the organism. ${ }^{29}$ However, an exacerbated production of this substance can result in nocive effects, such as deregulation of the immune response and changes in inflammatory modulation. Hypothalamic-pituitary-adrenal axis produces the cortisol production as a result of stress, which triggers this response on the central nervous system. . $^{13,16,30}$

In a long term, the cortisol can reduce the ability of the immune system by inhibiting immunoglobulins $A$ and $G$, altering the T-helper and T-suppressor balance, and causing modifications of Natural Killer cells. ${ }^{31-33}$ This combination of changes in inflammatory responses and depression of the immune system caused by elevated levels of cortisol in the body lead to the recognition of psychological stress as a potential factor for the pathogenesis of chronic diseases such as periodontitis. ${ }^{32,34}$
The literature highlights other pathophysiological factors that explain the principles of association among stress, high levels of cortisol and periodontitis. Studies in humans point out that psychological stress presents a relationship with periodontitis, elucidating elevated levels of IL-1 $\beta$ in patients who presented both conditions. ${ }^{35-37}$ The consequence of the imbalance of this cytokine deregulates the host response and also the resistance to pathogens, consequently aggravating damages in chronic lesions such as periodontitis. ${ }^{38}$

In animal model studies, greater periodontal destruction was demonstrated in stressed rats with an increase in pro-absorption factor (RANKL). ${ }^{39}$ The receptor activator of nuclear factor kappa-B ligand (RANKL) is a chemotactic factor responsible for forming and activating osteoclasts ${ }^{39}$ from macrophages precursor cells. Also, the proliferation of anaerobic bacteria and subsequent damage to the periodontium 
are favored with the increase in oxygen metabolism in the periodontal tissues. ${ }^{40,41}$

The methods of measurement of salivary and serum cortisol are used for the diagnostic categorization of chronic stress. Both methods are characterized as viable to obtain parameters that configure the stress. The serum cortisol evaluated by chemiluminescence and immunoassay techniques are the primary methods of choice in stress analysis. However, such techniques present biases related to the low specificity of the analysis antibodies and their considerable affinity for other steroidal hormones. ${ }^{42}$

Thus, the salivary cortisol measurement method has become more popular due to the diffusion of cortisol to saliva independently of the salivary flow, the ease of sample collection, and the better differentiation of analysis antibody bindings to steroid hormones. ${ }^{43,44}$ Only one study evaluated serum cortisol ${ }^{25}$ in this study all included patients are systemically healthy. Hilgert et $\mathrm{al}^{24}$ and Bakri et $\mathrm{al}^{22}$ use salivary cortisol measurement.

Besides blood and saliva, the increased cortisol levels in the gingival crevicular fluid were also associated with the severity of periodontitis. ${ }^{43-45}$ This is an aggravating factor in the disease in the absence of adequate treatment for the periodontal tissue in stressed patients. ${ }^{5,46}$

As for the analysis described in the articles selected for periodontitis, the World Health Organization advises that periodontal treatment should be recommended in teeth that have periodontal pockets above $3 \mathrm{~mm}$. For this, the PB examination should be performed. PB and the Community Periodontal Index of Treatment Needs are safe parameters for complete analysis of the presence, extent, and severity of periodontitis. ${ }^{47}$ In this review, all studies conducted PB and CAL for the diagnosis of periodontitis. ${ }^{22,24,25}$

In this context, $\mathrm{PB} \geq 4 \mathrm{~mm}$ and $\mathrm{CAL} \geq 5 \mathrm{~mm}$ are references adopted for moderate-to-severe periodontitis ${ }^{47,48}$ and used as a diagnostic method for periodontitis. Both PB values, 5 and $6 \mathrm{~mm}$, are characteristic of interventions that involve surgical procedures to reduce the clinical aspect of insertion loss. ${ }^{47,48}$ Therefore, factors such as stress may be related to this progression of severity in such patients.

To qualify the methods used in the studies, the Fowkes and Fulton ${ }^{20}$ checklist, adapted from Almeida et al, ${ }^{21}$ was adopted. This checklist assessed whether the methods applied in the observational studies are sufficient to produce coherent and useful information.

Bakri et al, ${ }^{22}$ presented more considerable methodological problems than other articles. ${ }^{24,25}$ The methods used to analyze the association between the studied conditions need a more reliable evaluation of periodontitis. Even though this study has used validated indexes, the absence of calibration of the evaluators increases discrepancies in the results obtained. Besides minor problems presented in the included studies from this review, a total of 747 articles were evaluated in three studies; it has been considered a good sample to reunite in a systematic review. ${ }^{49}$

It is remarkable that more studies have to be performed to elucidate this association. These studies have to evaluate not only methodologies measurables that evaluate cortisol levels and periodontal clinical parameters but also that follow-up patients for months or years to evaluate the influence of psychological stress on the initiation and progression of periodontitis. Interventional studies can be done too, to answer the dentistry and psychological therapeutics influence during periodontitis.

The selected articles suggest that stress is a relevant psychosocial factor and may be part of the various agents responsible for the multifactorial of the etiology of periodontitis ${ }^{13,16,17,30,50}$ These two comorbidities have a plausible physiopathological basis, and the association between them indicates that the maintenance of periodontal health is essential in patients with psychological stress. Also, if these patients undergo periodontal therapy, the response to treatment may be unfavorable. ${ }^{46,51}$

\section{Conclusion}

Although two articles highlight psychological stress as a modulator of alterations in periodontitis, more research is needed on this relationship using more sensitive methodological tools. It is important to emphasize the importance of new research that relates high levels of cortisol in the body to the level of alveolar bone loss, as well as longitudinal and interventional studies that assess whether stress therapies can contribute to the improvement of periodontal health in patients undergoing treatment of periodontitis.

\section{Conflict of Interest}

None declared.

\section{Acknowledgments}

The authors would like to thank the Federal University of Pará, specially CAPES (Coordenação de Aperfeiçoamento de Pessoal de Nível Superior - Finance Code 001) and PROPESP (Pró-Reitoria de Pesquisa e Pós Graduação).

\section{References}

1 Socransky SS, Haffajee AD, Cugini MA, Smith C, Kent RL, Jr. Microbial complexes in subgingival plaque. J Clin Periodontol 1998;25(2):134-144

2 Ebersole JL, Dawson D III, Emecen-Huja P, et al. The periodontal war: microbes and immunity. Periodontol 2000 2017;75(1):52-115

3 Hajishengallis G. Periodontitis: from microbial immune subversion to systemic inflammation. Nat Rev Immunol 2015;15(1):30-44

4 Bosshardt DD. The periodontal pocket: pathogenesis, histopathology and consequences. Periodontol 2000 2018;76(1):43-50

5 Takei N, Carranza K, Carranza. Periodontia Clínica. 12th ed. Brazil: Elsevier ; 2016

6 Genco RJ, Ho AW, Kopman J, Grossi SG, Dunford RG, Tedesco LA. Models to evaluate the role of stress in periodontal disease. Ann Periodontol 1998;3(1):288-302

7 Koo HS, Hong SM. Prevalence and risk factors for periodontitis among patients with metabolic syndrome. Metab Syndr Relat Disord 2018;16(7):375-381

8 P Kolte A, A Kolte R, N Lathiya V. Association between anxiety obesity and periodontal disease in smokers and non-smokers: a cross-sectional study. J Dent Res Dent Clin Dent Prospect 2016;10(4):234-240 
9 Monteiro da Silva AM, Oakley DA, Newman HN, Nohl FS, Lloyd HM. Psychosocial factors and adult onset rapidly progressive periodontitis. J Clin Periodontol 1996;23(8):789-794

10 Ng SK, Keung Leung W. A community study on the relationship between stress, coping, affective dispositions and periodontal attachment loss. Community Dent Oral Epidemiol 2006;34(4):252-266

11 Araújo MM, Martins CC, Costa LC, et al. Association between depression and periodontitis: a systematic review and meta-analysis. J Clin Periodontol 2016;43(3):216-228

12 Ballieux RE. Impact of mental stress on the immune response. J Clin Periodontol 1991;18(6):427-430

13 Boyapati L, Wang HL. The role of stress in periodontal disease and wound healing. Periodontol 2000 2007;44:195-210

14 Fishta A, Backé EM. Psychosocial stress at work and cardiovascular diseases: an overview of systematic reviews. Int Arch Occup Environ Health 2015;88(8):997-1014

15 Ayub LG, Júnior AB, Grisi MF, et al. Stress as possible risk factor for periodontal disease - literature review. R Periodontia 2010;20(3):28-36

16 Breivik T, Thrane PS, Murison R, Gjermo P. Emotional stress effects on immunity, gingivitis and periodontitis. Eur J Oral Sci 1996;1044( Pt 1):327-334

17 Oppermann RV, Alchien JC, de Castro GD. Stress effects on immunity and periodontal disease. Rev Fac Odontol P Alegre 2002;43(2):52-59

18 Moher D, Liberati A, Tetzlaff J, Altman DG, Group P; PRISMA Group. Preferred reporting items for systematic reviews and meta-analyses: the PRISMA statement. BMJ 2009; 339:b2535

19 Higgins JPT, Green S, Cochrane Handbook for Systematic Reviews of Interventions. Version 5.1.0 ed. Available from http://handbook.cochrane.org The Cochrane Collaboration; 2011

20 Fowkes FG, Fulton PM. Critical appraisal of published research: introductory guidelines. BMJ 1991;302(6785):1136-1140

21 Almeida A, Fagundes NCF, Maia LC, Lima RR. Is there an association between periodontitis and atherosclerosis in adults? A systematic review. Curr Vasc Pharmacol 2017;16(6):569-582

22 Bakri I, Douglas CW, Rawlinson A. The effects of stress on periodontal treatment: a longitudinal investigation using clinical and biological markers. J Clin Periodontol 2013;40(10):955-961

23 Goyal S, Jajoo S, Nagappa G, Rao G. Estimation of relationship between psychosocial stress and periodontal status using serum cortisol level: a clinico-biochemical study. Indian J Dent Res 2011;22(1):6-9

24 Hilgert JB, Hugo FN, Bandeira DR, Bozzetti MC. Stress, cortisol, and periodontitis in a population aged 50 years and over. J Dent Res 2006;85(4):324-328

25 Ishisaka A, Ansai T, Soh I, et al. Association of cortisol and dehydroepiandrosterone sulphate levels in serum with periodontal status in older Japanese adults. J Clin Periodontol 2008;35(10):853-861

26 Weik U, Herforth A, Kolb-Bachofen V, Deinzer R. Acute stress induces proinflammatory signaling at chronic inflammation sites. Psychosom Med 2008;70(8):906-912

27 Armitage GC. Development of a classification system for periodontal diseases and conditions. Ann Periodontol 1999;4(1):1-6

28 Cook DJ, Mulrow CD, Haynes RB. Systematic reviews: synthesis of best evidence for clinical decisions. Ann Intern Med 1997;126(5):376-380
29 Brunton LL, Hilal-Dandan R. Goodman \& Gilman's Manual of Pharmacology and Therapeutics. 2nd ed. New York, NY: McGraw-Hill Education; 2008

30 Warren KR, Postolache TT, Groer ME, Pinjari O, Kelly DL, Reynolds MA. Role of chronic stress and depression in periodontal diseases. Periodontol 2000 2014;64(1): 127-138

31 Irwin M, Patterson T, Smith TL, et al. Reduction of immune function in life stress and depression. Biol Psychiatry 1990;27(1):22-30

32 Mesa F, Magán-Fernández A, Muñoz R, et al. Catecholamine metabolites in urine, as chronic stress biomarkers, are associated with higher risk of chronic periodontitis in adults. J Periodontol 2014;85(12):1755-1762

33 Parwani R, Parwani SR. Does stress predispose to periodontal disease? Dent Update 2014;41(3):260-264, 267-268, 271-272

34 Azuma K, Adachi Y, Hayashi H, Kubo KY. Chronic psychological stress as a risk factor of osteoporosis. J UOEH 2015;37(4):245-253

35 Deinzer R, Kottmann W, Förster P, Herforth A, Stiller-Winkler $\mathrm{R}$, Idel $\mathrm{H}$. After-effects of stress on crevicular interleukin1beta. J Clin Periodontol 2000;27(1):74-77

36 Giannopoulou C, Kamma JJ, Mombelli A. Effect of inflammation, smoking and stress on gingival crevicular fluid cytokine level. J Clin Periodontol 2003;30(2):145-153

37 Lopez-Castejon G, Brough D. Understanding the mechanism of IL-1ß. secretion. Cytokine Growth Factor Rev 2011;22(4):189-195

38 Mousavijazi M, Naderan A, Ebrahimpoor M, Sadeghipoor M. Association between psychological stress and stimulation of inflammatory responses in periodontal disease. J Dent (Tehran) 2013;10(1):103-111

39 Peruzzo DC, Benatti BB, Antunes IB, et al. Chronic stress may modulate periodontal disease: a study in rats. J Periodontol 2008;79(4):697-704

40 Huang S, Lu F, Zhang Z, Yang X, Chen Y. The role of psychologic stress-induced hypoxia-inducible factor- $1 \alpha$ in rat experimental periodontitis. J Periodontol 2011;82(6):934-941

41 Ardila CM, Guzmán IC. Association of Porphyromonas gingivalis with high levels of stress-induced hormone cortisol in chronic periodontitis patients. J Investig Clin Dent 2016;7(4):361-367

42 El-Farhan N, Rees DA, Evans C. Measuring cortisol in serum, urine and saliva - are our assays good enough? Ann Clin Biochem 2017;54(3):308-322

43 Cakmak O, Alkan BA, Ozsoy S, Sen A, Abdulrezzak U. Association of gingival crevicular fluid cortisol/dehydroepiandrosterone levels with periodontal status. J Periodontol 2014;85(8):e287-e294

44 Cakmak O, Tasdemir Z, Aral CA, Dundar S, Koca HB. Gingival crevicular fluid and saliva stress hormone levels in patients with chronic and aggressive periodontitis. J Clin Periodontol 2016;43(12):1024-1031

45 Axtelius B, Edwardsson S, Theodorsson E, Svensäter G, Attström R. Presence of cortisol in gingival crevicular fluid. A pilot study. J Clin Periodontol 1998;25(11 Pt 1):929-932

46 Dantas FT, Martins SHL, Dantas ATM, Gnoatto M. Stress and periodontal disease - A literature review. Braz J Periodontol 2016;26(3):19-28

47 Lindhe J, Socransky SS, Nyman S, Haffajee A, Westfelt E. “Critical probing depths" in periodontal therapy. J Clin Periodontol 1982;9(4):323-336 
48 Heitz-Mayfield LJ, Trombelli L, Heitz F, Needleman I, Moles D. A systematic review of the effect of surgical debridement vs non-surgical debridement for the treatment of chronic periodontitis. J Clin Periodontol 2002;29(Suppl 3): 92-102, discussion 160-162

49 Guyatt G, Oxman AD, Akl EA, et al. GRADE guidelines: 1. Introduction-GRADE evidence profiles and summary of findings tables. J Clin Epidemiol 2011;64(4):383-394
50 Rettori E, De Laurentiis A, Dees WL, Endruhn A, Rettori V. Host neuro-immuno-endocrine responses in periodontal disease. Curr Pharm Des 2014;20(29):4749-4759

51 Wimmer G, Köhldorfer G, Mischak I, Lorenzoni M, Kallus KW. Coping with stress: its influence on periodontal therapy. J Periodontol 2005;76(1):90-98 